\title{
SUSAN BASSNETT
}

University of Warwick

s.bassnett@warwick.ac.uk

\section{PRZEKŁAD I POSTKOLONIALIZM}

\section{Abstract}

\section{Translation and Postcolonialism}

This paper will seek to trace two lines of post-colonial theorizing about translation, one of which can loosely be termed post-colonial literary theory and the other as translation studies. Both of these fields rose to prominence and developed in the latter decades of the twentieth century. It will be argued that research is currently moving towards an integration of the two approaches that offers exciting new possibilities for the future.

Key words: translation, post-colonial theory, cultural turn, translational turn

Słowa klucze: przekład, postkolonializm, zwrot kulturowy, zwrot przekładowy

\section{Wprowadzenie}

W XXI wieku przekład zyskał znaczenie globalne w związku z rewolucją w komunikacji elektronicznej oraz faktem, że miliony ludzi - więcej niż kiedykolwiek dotąd - wędrują po naszej planecie. Przemieszczając się, przenoszą z sobą swoje języki, praktyki kulturowe, systemy wierzeń, a zatem, spotykając się z innymi ludźmi, dokonują pewnej formy przekładu. Negocjowanie różnic odbywa się zarówno w sferze językowej, jak i kulturowej, dlatego nie może zaskakiwać rosnące obecnie zainteresowanie teorią i praktyką przekładu. Realizuje się ono w dwóch odrębnych, ale powiązanych z sobą dziedzinach, które nabrały znaczenia i rozwinęły się w ostatnich dekadach dwudziestego wieku: w szeroko rozumianej krytyce postkolonialnej oraz w przekładoznawstwie. Niniejszy artykuł jest próbą 
prześledzenia tych dwóch nurtów postkolonialnej teorii przekładu, i prowadzi do wniosku, że prowadzone obecnie badania zmierzają do integracji obu metod, która otwiera nowe, pasjonujące możliwości badawcze.

\section{Pomiędzy}

W słynnym eseju Jak nowe przychodzi do tego świata: Przestrzeń ponowoczesna, czasy postkolonialne i problemy przekładu kulturowego, z książki Miejsca kultury, Homi Bhabha przedstawia teorię sfery „,pomiędzy”, którą uznaje za nowe zjawisko globalne, „nową kartografię międzynarodowej przestrzeni niespójnych rzeczywistości historycznych" (Bhabha 2010: 237). Ta niespójna przestrzeń to przestrzeń migrancka lub nomadyczna, w której pewność i ciągłość zostają zaburzone, tożsamości rozpadają się i odtwarzają $\mathrm{w}$ wirze zmiany i niepewności, a jednak jest to przestrzeń niezwykle kreatywna. Bhabha skupia się na idei nieskończonego ruchu i przekształcania, podkreślając ambiwalencję samego przekładu, odbywającego się pomiędzy dwoma miejscami, w przestrzeni pogranicznej, która jednocześnie należy i nie należy do każdej ze stron: ani do kultury źródłowej, ani docelowej. Sprzeczność będąca istotą przekładu polega na tym, że choć tłumacz podejmuje próbę przeniesienia tekstu powstałego $\mathrm{w}$ jednym kontekście w inny kontekst na tyle skutecznie, na ile potrafi, to sam akt thumaczenia zmusza go do zmierzenia się z tymi aspektami tekstu, które aktywnie przeciwstawiają się przekładowi. Jednym z poziomów zadania tłumacza jest zatem radzenie sobie z problemem nieprzekładalności. Jak stwierdził amerykański językoznawca Edward Sapir:

żadne dwa języki nie są nigdy dostatecznie podobne, by można je było traktować jako reprezentujące tę samą rzeczywistość społeczną. Światy, w których żyją różne społeczeństwa, są odrębnymi światami, nie zaś tym samym światem, tylko opatrzonym odmiennymi etykietkami (Sapir 1978: 88).

Różnica jest zatem istotą każdego przedsięwzięcia translatorskiego, ponieważ tekst opiera się asymilacji, zdania zbudowane w jednym języku nie pozwalają się przenieść do innego języka w dokładnie tej samej formie. Rzecz wyrażona za pomocą jednego języka nie może być wciśnięta w kaftan drugiego. Ekwiwalencja między językami jest zatem zawsze wynikiem negocjowania przestrzeni ,pomiędzy”. Dla Bhabhy ,pomiędzy” to przestrzeń silnie obciążona, na której ,spoczywa odpowiedzialność za znaczenie kultury” (Bhabha 
2010: 25). Można zatem stwierdzić, że to właśnie jest przestrzeń przekładu. O przestrzeni zajmowanej przez tłumacza często mówi się metaforycznie „ziemia niczyja”, co podsuwa liczne skojarzenia z polem bitwy. Gdy Bhabha pisze o nowym zjawisku ,kultury migranckiej”, używa terminologii przekładoznawczej. Migracja postkolonialna jest dla niego zjawiskiem translacyjnym, stanem, w którym znaczenie stale podlega przekształceniom w spotkaniach $\mathrm{z}$ innymi kulturami. Migracja jest przeciwieństwem kolonializmu, który usiłował reprodukować oryginał i narzucać ramy polityczne, społeczne, etyczne i estetyczne oryginału innym kulturom. Szukając języka, za pomocą którego można by opisywać kulturę migrancką, zajmującą nową przestrzeń pomiędzy znanymi, ustalonymi przestrzeniami, Bhabha używa takich terminów jak hybrydyczność, graniczność, różnorodność. Nowość, o której mówi, dotyczy dyskursu migranckiego czy mniejszościowego, a powstaje, jak pisze Bhabha, dzięki ,przekładowi kulturowemu”. Nowość przychodząca na świat rodzi się dzięki wymianom, spotkaniom, wyzwaniom, interpretacji, przyswajaniu, przeciwstawianiu, transponowaniu, przeformułowywaniu, zapominaniu, wynajdywaniu, wyobrażaniu; krótko mówiąc - dzięki przekładowi.

$\mathrm{Z}$ tego powodu już w połowie lat 90 . XX wieku przekład zyskał w pisarstwie postkolonialnym znaczenie metaforyczne, jako termin sugerujący ruch, spotkania międzykulturowe i redefiniowanie tożsamości. Walter Benjamin przedstawił przekład jako dalsze życie (Fortleben), sposób na pozagrobowe życie tekstu, który bez przekładu popadłby w nieczytanie i zapomnienie. Myśl ta zyskała nowe znaczenie w świecie postkolonialnym, zwłaszcza dzięki Derridiańskiej interpretacji Benjamina, która przesuwa się w kierunku koncepcji sur-vivre, czyli życia na krawędzi, na pograniczu, na granicy.

\section{Przekład kulturowy}

Z terminologii przekładoznawczej coraz chętniej korzysta też antropologia kulturowa, odmienna od literatury i krytyki postkolonialnej, choć poruszająca się mniej więcej po osiach do nich równoległych. Zarówno James Clifford, jak i Clifford Geertz mówią o powierzchownej reprezentacji odmiennych kultur w obrębie dyskursu antropologicznego, podkreślając, że antropolog konstruuje swoją wersję odmiennej kultury podobnie, jak czyni to tłumacz. Tak jak tłumacz odgrywa główną rolę w nadawaniu kształtu przekładowi, antropolog lub etnograf odgrywa główną rolę w nadawaniu kształtu swoim odkryciom. Terminu ,przekład kulturowy” 
zaczęto używać jako wytrychu pozwalającego mówić o procesie, w jakim biorą udział antropolodzy. W tym przypadku jednak użycie tego terminu niezupełnie pokrywa się ze sposobem jego rozumienia przez Bhabhę, a w latach 90. XX wieku najwyraźniej staje się on terminem-workiem, stosowanym luźno do opisu procesów interpretacji różnych systemów znakowych dokonujących się ponad i na granicach między kulturami. Talal Asad wskazywał na znaczenie różnicy między przekładem rozumianym w sposób metaforyczny (odnoszonym do fizycznego doświadczenia spotkań międzykulturowych) a przekładem jako przenoszeniem tekstów ponad granicami językowymi. To rozróżnienie jest niezwykle istotne, a jego niezrozumienie może prowadzić do zamętu terminologicznego i metodologicznego (Asad 1986).

Podobnie Tejaswini Niranjana odrzuca takie koncepcje przekładu zarówno w badaniach literackich, jak i w etnografii - które nie biorą pod uwagę asymetrycznych relacji władzy w kontaktach między językami. Uznawanie przekładu za przejrzyste, bezstronne medium w jej opinii jest nie tylko naiwnością, ale może też być szkodliwe i służyć utrzymywaniu relacji hegemonicznych. Przekład, jak pisze, ,umacnia(ł) hegemoniczne wersje ludzi skolonizowanych, umożliwiając im przyjmowanie statusu określanego przez Edwarda Saida mianem reprezentacji obiektów pozbawionych historii" (Niranjana 1992: 176). Niranjana domaga się położenia większego nacisku na konteksty kulturowe, w których dochodzi do przekładu, twierdząc, że tłumaczenia należy widzieć jako relacje wzajemności, kształtujące i przekształcające ustalone koncepcje kultury i tożsamości.

Użycie przekładu jako terminu metaforycznego do badania kontekstów postkolonialnych nie zostało jednak powszechnie przyjęte. Nie bierze ono bowiem pod uwagę dobrze zakorzenionej koncepcji przekładu jako przeniesienia tekstu pomiędzy językami. Przekład kulturowy to pojęcie atrakcyjne, które jednak skupia się na samej idei wymiany, nie na rzeczywistości kontaktu międzyjęzykowego. Korzystanie z terminologii przekładoznawczej przez osoby jednojęzyczne otwarcie atakuje Harish Trivedi:

Zatem posługiwanie się we współczesnym dyskursie teoretycznym terminem przekładu postkolonialnego trąci tautologią. Wydaje się, że w naszej erze (dodatniej waloryzacji) migracyjności, uchodźstwa i diaspory samo słowo „translacja” zatoczyło pełny krąg i wróciło od metaforycznego, literackiego znaczenia transakcji międzyjęzykowej do etymologicznego, fizycznego znaczenia zakłócenia przestrzennego. Zdaje się, że sam przekład został przetłumaczony z powrotem do swoich źródeł (Bassnett, Trivedi 1999: 13). 
Trivedi mówi z pozycji wielojęzycznego badacza, dobrze zorientowanego zarówno w zachodnich teoriach postmodernistycznych i postkolonialnych, jak i w dyskusjach dotyczących przekładu, które toczą się w Indiach, bodaj najmocniej zróżnicowanym pod względem językowym kraju na świecie. Trivediego interesuje zjawisko zawłaszczania dyskursu przekładoznawczego przez badaczy, którzy nie potrafią przekładać, ponieważ funkcjonują wyłącznie w jednym języku. Jego krytyka zjawisk, które postrzega jako modne intelektualne trendy marginalizujące przekład międzyjęzykowy, jest prowokacyjna i zmusza do namysłu. W artykule z roku 2007 Trivedi atakuje jednak także inną grupę badaczy (wywodzącących się, jak sami twierdzą, z badań nad przekładem) za nieskuteczny sprzeciw wobec rozprzestrzeniania się metaforycznego użycia pojęcia przekładu. Trivedi odnosi się do tekstów Susan Bassnett i André Lefevere’a, zwłaszcza zaś do ich książki Constructing Cultures z 1998 roku, w której autorzy wyrażali nadzieję, że przekładoznawstwo i studia kulturowe (w ich możliwie najszerszym rozumieniu) mogą wspólnie podjąć badania nad powstawaniem tekstowego kapitału kulturowego funkcjonującego ponad granicami kulturowymi oraz nad etnocentryczną przemocą i polityką przekładu. Zdaniem Trivediego, do takiego połączenia sił nie doszło, a obie wymienione dziedziny badań, w latach 80 . XX wieku kwestionujące zastany stan rzeczy, raczej nie zmierzają w tę samą stronę.

\section{Zwrot kulturowy w badaniach nad przekładem}

Równolegle z rozwojem teorii postkolonialnej rozwijała się także dziedzina badań przekładoznawczych (translation studies). Powszechnie uznaje się, że sam termin translation studies został ukuty przez przekładoznawcę Jamesa Holmesa w eseju The Name and Nature of Translation Studies, wydanym w roku 1972. Holmes, co ważne, odrzucił koncepcję ekwiwalencji jako identyczności międzyjęzykowej i skupił się na zachodzącym w procesie przekładu złożonym procesie negocjacji. Jego poglądy podzielała wówczas niewielka międzynarodowa grupa badaczy reprezentujących różne dyscypliny, z czasem jednak status i wiarygodność przekładoznawstwa zaczęły się umacniać. W centrum tego obszaru badań na wczesnym etapie znalazły się dwie kwestie: konieczność analizy tekstów w kontekstach oraz konieczność odrzucenia przestarzałych wartościujących koncepcji przekładu, co pozwoliłoby rozpatrywać przetłumaczony tekst jako czynnik 
innowacji i odnowy w literaturze docelowej. Opublikowany w roku 1978 esej autorstwa izraelskiego badacza Itamara Even-Zohara stał się podstawą kolejnego etapu rozwoju młodej dyscypliny, jako że opisywał metodę badania roli, jaką przekłady odgrywają w historii literatury. Even-Zohar zauważał, że w pewnych okresach aktywność tłumaczeniowa jest znacząca, w innych zaś nie tłumaczy się nic lub prawie nic. Stwierdził też, że w niektórych kulturach tłumaczenia są zjawiskiem częstszym niż w innych. Dowodził wreszcie, że teksty przetłumaczone różnią się zarówno jeśli chodzi o sposób odbioru, jak i potencjalne znaczenie, a niektóre stają się istotnym źródłem innowacji. Na podstawie tych obserwacji Even-Zohar sformułował teorię zakładającą istnienie trzech podstawowych warunków sprzyjających powstawaniu licznych przekładów:

1) kiedy literatura jest „młoda”, trwa proces jej powstawania; 2) kiedy literatura jest albo „peryferyjna” (w obrębie dużej grupy skorelowanych literatur), albo „słaba”, albo też przejawia obie te cechy; 3) kiedy w dziejach literatury następują punkty zwrotne, momenty kryzysowe lub kiedy tworzy się w niej pewnego rodzaju próżnia literacka (Even-Zohar 2009: 199).

Założenie to odegrało istotną rolę i doprowadziło w pierwszej kolejności do rozwoju badań nad historią przekładu w różnych kontekstach, co z kolei stało się wyzwaniem dla obowiązujących historii literatury, mających tendencję do marginalizowania lub lekceważenia znaczenia przekładu jako czynnika kształtującego literatury narodowe. Łatwo to wyjaśnić: historie literatur narodowych są ściśle powiązane z problemami narodowej tożsamości, a uznanie roli tłumaczeń oznacza zgodę na uznanie systemów literackich za hybrydy, nie zaś za zjawiska o charakterze wyłącznie rodzimym. Co więcej, narodowy model historii literatury zazdrośnie strzeże swych granic. André Lefevere zwięźle podsumowuje tendencyjność leżącą u podstaw znacznej części historii literatury w XIX i XX wieku:

Pisane do niedawna historie literatur narodowych poświęcały tłumaczeniom bardzo niewiele uwagi lub nie poświęcały im jej wcale, jako że dla historyka literatury przekład to wyłącznie zagadnienie ,języka", nie literatury. Jest to kolejna pochodna „monolingwizacji” historii literatury przez romantycznych historiografów próbujących tworzyć literatury „,narodowe”, w miarę możliwości zupełnie wolne od zanieczyszczeń w postaci obcych wpływów (Lefevere 1992: 39).

Lefevere mówi tu o monolingwizacji, ale problem jest o wiele szerszy. Na przykład, dopiero niedawno termin ,literatura angielska” zaczął oznaczać 
literaturę pisaną przez Anglików, czyli jedną z wielu literatur powstających języku angielskim. Wcześniej posługiwano się nim w sposób elitarystyczny, zakładający istnienie hierarchii wartości, oznaczającej wykluczenie wszystkiego, co nie jest godne miana „literatury angielskiej”. Wole Soyinka wspomina, że gdy w latach 70 . XX wieku zaproszono go z wykładami do Cambridge, musiał o literaturze afrykańskiej wykładać na Wydziale Antropologii Społecznej, jako że Wydział Anglistyki ,nie uznawał istnienia tworów w rodzaju «literatury afrykańskiej»” (Soyinka 1976: vii). Tendencja do strzeżenia granic literatury angielskiej doprowadziła do sytuacji, którą obecnie uznalibyśmy za absurdalne nadużycie, choć miała ona miejsce nie w latach 30., ale 70. XX wieku, a więc wcale nie tak dawno temu.

Skupiając się na znaczeniu przekładu w systemie literatury docelowej badania przekładoznawcze mogły porzucić wcześniejsze dyskusje nad tym, czy tłumaczenie jest ,wiernym” odpowiednikiem oryginału. Takie debaty nie miały teoretycznych podstaw i były niezwykle subiektywne, jako że nie da się ustalić kryteriów oceny wierności transferu tekstowego, skoro koncepcje absolutnej ekwiwalencji językowej są nie do utrzymania, a kanony estetyki zmieniają się w czasie. Przekładoznawstwo wykorzystało teorię recepcji, badania kulturowe $\mathrm{i}$ intertekstualne, a kładąc nacisk na postrzeganie procesu przekładu w podwójnym kontekście: oryginału (źródła) i kultury docelowej, skutecznie wprowadziło do dyskusji o przekładzie wymiar ideologiczny i wpisane $\mathrm{w}$ transfer tekstu procesy manipulacji.

Na początku lat 90. XX wieku przekładoznawstwo stało się już ważną dziedziną badawczą. Na uniwersytetach i w college'ach zaczęły się pojawiać programy kształcenia w tej dziedzinie, a na całym świecie - czasopisma naukowe, wydawnictwa monograficzne, rozprawy doktorskie i międzynarodowe konferencje poświęcone przekładoznawstwu. Nowe podejście do zagadnienia przekładu było atrakcyjne dla młodszego pokolenia, wielojęzycznego i wielokulturowego, zaś zauważalny w naukach o przekładzie nacisk na to, by wiązać teorię z praktyką i za jej pośrednictwem ją weryfikować, wymuszał interdyscyplinarność, w ramach której historia społeczna i kulturowa łączyła się z filozofią języka w szczegółowej analizie tekstu. Kluczowym słowem w tej fazie rozwoju badań nad przekładem stała się „widzialność”: widzialność tłumacza tworzącego tekst, widzialność mechanizmów produkcji i rozpowszechniania tekstu, widzialność strategii wykorzystywanych przez tłumacza w samym tekście. W wydanej w roku 1995 książce The Translator's Invisibility: A History of Translation Lawrence Venuti podjął próbę zmiany sposobu postrzegania tłumaczeń i tłumaczy, podkreślając rolę 
tłumacza jako drugiego autora, a nie tylko anonimowego filtru, przez który, niczym w jakimś tajemniczym procesie alchemicznym, przepuszczany jest tekst. Venuti wzywał do zmiany współczesnego myślenia o przekładzie nie tylko po to, by uznać historyczne znaczenie tłumaczeń, ale też by pojąć, jak złożona jest przekładowa praktyka literacka, i by na tej podstawie ją oceniać.

Drugim - obok troski o zwiększenie widzialności zarówno tłumaczeń, jak i tłumaczy - głównym kierunkiem rozwoju przekładoznawstwa w latach 90. XX wieku był tak zwany „zwrot kulturowy”, którego prezentacją był m.in. zbiór prac Translation, History and Culture, pod redakcją Susan Bassnett i André Lefevere'a, wydany w roku 1990. We wprowadzeniu do tego tomu czytamy:

Rozwój badań nad przekładem wskazuje, że podobnie jak wszystkie inne formy (prze)pisania thumaczenie nigdy nie jest niewinne. Zawsze istnieje jakiś kontekst, w którym dochodzi do tłumaczenia, zawsze jest jakaś historia, z której wyłania się tekst, i historia, do której tekst jest przenoszony. (...) Przekład jest ważną siłą kształtującą rozwój światowej kultury, a porównawcze badania literatury nie są możliwe bez uwzględnienia przekładów (Bassnett, Lefevere 1990: 12).

Założenia zwrotu kulturowego były jasne: przekład należy uznać za aktywność literacką, odgrywającą główną rolę w rozwoju poszczególnych literatur narodowych; należy uznać, że literatury są dzięki tłumaczeniom wzajemnie powiązane, oraz że przekłady nie pojawiają się w próżni, jako że zawsze istnieje podwójny kontekst historyczny.

Wraz z rozwojem przekładoznawstwa, na znaczeniu zyskiwały takie obszary badawcze, jak przekład i gender, przekład i relacje władzy, przekład i globalizacja.

Bardzo ważnym obszarem stały się także badania postkolonialne. Walter Benjamin przypomina nam, że oryginał jest ściśle związany z przekładem, że łączą je bliskie więzi, jako że bez oryginału przekład nie może zaistnieć. Musi uprzednio istnieć tekst, aby mogło powstać tłumaczenie, zawsze gdzieś indziej istnieje punkt wyjścia dla przekładu. Przekład wydarza się między językami i kulturami, zatem stanowi proces międzykulturowy, równocześnie jednak także międzyczasowy, bo oryginał pojawił się gdzie indziej i kiedy indziej. Oznacza to, że przekład zawsze zakłada pamięć, bez względu na to bowiem, jak daleko odejdzie od oryginału, pamięć o nim zawsze pozostaje. Przekład można więc postrzegać jako proces transformacji, rodzaj podróży od źródła do celu, podobnie jak to jest w akcie pamiętania. 
Jednym z zagadnień przekładoznawstwa postkolonialnego są nierówne relacje władzy między kulturami, a co za tym idzie - między językami. Ich wynikiem był jednokierunkowy przepływ tłumaczeń, jako że w okresie kolonialnym istniała tendencja do tłumaczenia tekstów na języki europejskie, by mogli je konsumować europejscy czytelnicy; nie dochodziło tu zatem do wzajemnej wymiany. Tłumaczenia $\mathrm{z}$ języków europejskich wiązały się głównie z działalnością misjonarską - tłumaczono przede wszystkim Biblię i inne święte teksty. Pozytywnym rezultatem tej sytuacji było uratowanie licznych języków lokalnych, jako że pierwsi tłumacze Biblii często układali pionierskie dwujęzyczne słowniki i opisywali gramatykę języków, na które tłumaczyli. Negatywnym skutkiem był z kolei fakt, że w procesie zabezpieczania rdzennych języków dochodziło do ich przeformułowywania zgodnie z europejskimi systemami kodyfikacyjnymi. Przedsięwzięcia tego rodzaju często były owocem współpracy, w której brali udział europejscy misjonarze thumacze i konwertyci posługujący się miejscowym językiem. Isabel Hofmeyr w swojej pouczającej książce The Portable Bunyan: A Transnational History of ,, The Pilgrim's Progress" opisuje wyniki ich współdziałania jako „stworzony przez misjonarzy język, nie zawsze w pełni rozpoznawalny dla swoich użytkowników, oraz świat nadzoru rasowego nad produkcją literacką i kulturową" (Hofmeyr 2004: 22).

Względna jednostronność działalności przekładowej między językami europejskimi i pozaeuropejskimi ujawnia także podstawowy problem, będący sednem rozważań o znaczeniu tłumaczenia per se. Przed XVII wiekiem status tłumaczenia bynajmniej nie był niższy od statusu tekstów „oryginalnych”. Tak naprawdę samą koncepcję „oryginalności” można uznać za innowację, która narodziła się gdzieś w wieku XVII, gdy na znaczeniu zaczęły zyskiwać prawa własności tekstów. Kiedy zaczęto postrzegać tłumaczenia jako do pewnego stopnia gorszą formę piśmiennictwa, ich status obniżył się, co widać w metaforycznym języku stosowanym w odniesieniu do przekładów. Podczas gdy w wieku XVI czasownik, ,przekładać” (to translate) był synonimem do ,anglicyzować” (to English), a metafory tłumaczenia mówiły o szukaniu skarbu czy zamianie ubrań, to już wiek później język metaforyczny był o wiele bardziej pejoratywny, a przekłady rozumiano jako „kopie” czy też „zwierciadła” przykładane do o wiele lepszego oryginału. Pojawiło się przekonanie, że przekłady to pisarstwo z drugiej ręki i drugiej jakości. Nie jest kwestią przypadku, że tego rodzaju zmiana dokonała się w okresie wielkiej ekspansji kolonialnej. Same kolonie można postrzegać jako przekłady „Wielkiego Europejskiego Oryginału” - oto wyeksportowano 
wizję Europy, a kolonia miała się stać odwzorowaniem doskonalszego oryginału, który istnieje gdzieś indziej, kiedy indziej. Zarówno przekład, jak i kolonia zatem, chociaż powiązane z oryginałem, uznawane były za mniej doskonałe, za kopie lub odbicia wielkiego źródła.

Sytuacja ta doprowadziła także do nierówności natury praktycznej, wzmacnianych przez przekłady na język hegemona. Eric Cheyfitz, na przykład, badał, jak europejscy kolonizatorzy wykorzystywali przekład do przejmowania praw własności ziemi. Analizując XVII-wieczną broszurę A True Declaration of the Colonie in Virginia, Cheyfitz wskazuje, że prawne uzasadnienie przejęcia ziemi od plemion algonkińskich opiera się na dokumencie, na podstawie którego lokalny wódz Paspehay otrzymał koronę i berło w zamian za ,ziemię do zaludnienia i objęcia w dziedziczne posiadanie". Cheyfitz zauważa:

Najpierw Anglicy przekładają Paspehaya na angielskie stosunki własności (a także na angielskie stosunki polityczne, nadając mu tytuł „króla”, co jest standardowym thumaczeniem na język angielski pochodzącego z języka algonkińskiego słowa weroance), dzięki czemu mogą uznać, iż „sprzedał” im „swoją" ziemię, a oni, zgodnie z „prawniczą" logiką swojego języka, mogą dzięki temu wziąc tę ziemię „w posiadanie”. Anglicy przekładają ziemię wykorzystywaną przez Paspehaya i jego rodaków, której jednak nikt nie ,posiada" (w każdym razie nie w językach algonkińskich), na własność Paspehaya (Cheyfitz 1991: 60).

Prawne następstwa tego aktu przekładu utrzymywały się aż po wiek XX; podobnie było z następstwami traktatu podpisanego w Waitangi w 1840 roku przez przedstawicieli Korony Brytyjskiej i ponad pięciuset wodzów maoryskich z Nowej Zelandii. Traktat ten przez jakiś czas podawano jako przykład wzorowej współpracy między kolonizatorem a kolonizowanym, ale Sabine Fenton i Paul Moon wskazywali, że to kwestia przekładu okazała się przyczyną wielkiego rozgoryczenia, a następnie sporów prawnych. Dokonany w roku 1869 ponowny przekład traktatu, mający rozwiązać problem „budzącego wstręt języka maoryskiego" z pierwszej wersji, ujawnił znaczące różnice i otworzył możliwość podważania warunków porozumienia opisanych w dokumencie z 1840 roku. Dopiero w 1975 roku powołano do życia Trybunał Waitangi, zajmujący się skargami, których źródłem były błędy zawarte w pierwotnym tłumaczeniu - błędy, które mogły, choć nie musiały być zamierzone. Jak twierdzą Fenton i Moon, w przypadku traktatu z Waitangi, 
Przekład staje się tym bardziej problematyczny, im silniejsza jest różnica między kulturami źródłową i docelową. (...) Gdy do różnic między dwiema kulturami dochodzi znacząca dysproporcja władzy, kultura staje się nieprzekładalna (Fenton, Moon 2002: 41-42).

Zarówno przypadek Algonkinów, jak i Maorysów to przykłady sytuacji, w której różne języki dysponują różną siłą, a tłumaczenie może pozbawić władzy nie tylko jednostkę, ale także całe kultury. Przekład odegrał ogromną rolę jako narzędzie budowy systemów i struktur kolonialnych, choć do niedawna badacze nie przywiązywali do tej kwestii zbyt wielkiej wagi. Tymczasem przekładoznawstwo potrafi zająć się bezpośrednio problemem dysproporcji w stosunkach władzy między językami i obnażać manipulacje leżące u podstaw aktu tłumaczenia.

Nawet jeśli polityczne znaczenie przekładu jest mniej jawne, tłumacze niewątpliwie tworzą teksty dostosowane do czytelników docelowych, a zatem w trakcie pracy stosują normy znane tym właśnie czytelnikom. Przekład staje się sposobem ubierania tego, co obce w formy tekstualne akceptowalne dla kultury docelowej.

Mahasweta Sengupta zwraca uwagę na proces tworzenia reprezentacji, zmuszający tłumaczy do konstruowania wyobrażeń Innego umożliwiających utrzymanie lub rozszerzenie hegemonii kultury dominującej. Badaczka zauważa też, że już sam wybór tekstów do tłumaczenia jest pierwszym etapem tego manipulacyjnego procesu.

Kształtując tożsamość akceptowalną dla kultury dominującej, tłumacz wybiera i przepisuje jedynie te teksty, które pasują do „obrazu” kultury źródłowej funkcjonującego w kulturze docelowej. Owo przepisywanie często wiąże się z intensywną manipulacją i upraszczaniem, by zyskać uznanie ze strony metropolii i w jej obrębie (Sengupta 1995: 160).

W ten sposób konstruuje się i ujednolica obraz innej kultury oraz oczekiwania, z których zaspokajaniem będą się mierzyć kolejni tłumacze. Stworzony przez dobrego thumacza obraz danej kultury bardzo trudno zmienić, niezależnie od tego, jak ów obraz w ogóle powstawał. Pisząc o literaturach Indii, Sengupta dowodzi, że ze względu na selektywny proces przekładu powstał szczególnie problematyczny obraz pisarstwa indyjskiego - obraz indyjskiej kultury, w którym na pierwszym planie są prostota, naturalność i dziecięca niewinność. Począwszy od sir Williama Jonesa, tłumacze usuwali śmiałą erotykę i decydowali się na tłumaczenie tekstów religijnych czy 
duchowych, utwierdzając obraz Indii jako „,bezpiecznie uległych, niezwykle odmiennych i raczej oswojonych w stosunku do dominującej władzy" (Sengupta 1995: 162).

Jeden z najbardziej prowokacyjnych impulsów postkolonialnych w badaniach nad przekładem pochodzi od pisarzy i teoretyków brazylijskich. Intelektualiści w całej Ameryce Łacińskiej, także w Brazylii, przez dziesięciolecia spierali się o to, jak przemyśleć wzajemne wpływy między ich kulturami a kulturą dawnych europejskich kolonizatorów. Problemem były relacje między rozwijającymi się tam tradycjami pisarskimi a literaturami europejskimi, które czytano i absorbowano. Pisarze na całym kontynencie musieli znaleźć sposób na zdobycie miejsca we własnych kulturach bez narażenia się na zarzut „kopiowania” wzorców europejskich, ale też bez odrzucania wszystkich wartości pochodzących z Europy. W roku 1928 brazylijski pisarz Oswald de Andrade opublikował słynny Manifesto Antropófago ${ }^{1}$, w którym błyskotliwie i dogłębnie przemyślał pewien epizod $\mathrm{z}$ historii kraju, wskazując tym samym drogę brazylijskim intelektualistom.

Mowa o incydencie z XVI wieku, kiedy to plemię Tupinamba zabiło i zjadło katolickiego misjonarza, ojca Sardinhę. Wydarzenie to oburzyło współczesnych, jako że kanibalizm dla europejskich chrześcijan stanowił najwyższe tabu. Tymczasem dla ludzi z plemienia Tupi zjedzenie darzonego szacunkiem obcego nie było barbarzyństwem, lecz swego rodzaju hołdem i wyrazem uznania dla znaczenia chrześcijańskiego kapłana. W pewnym sensie powiedzieć można, że Tupiowie dosłownie przetłumaczyli chrześcijańską zasadę Eucharystii, w której symbolicznie i rytualnie konsumuje się ciało i krew Chrystusa. De Andrade, wracając do tego epizodu, zauważył, że Brazylijczycy są potomkami zarówno pożerających, jak i pożeranych, dlatego zaproponował alternatywny sposób postrzegania relacji łączących ich z Europą. Krótko mówiąc, wszystko, co pochodzi z Europy, może posłużyć wzmocnieniu kultury brazylijskiej, o ile zostanie ,pożarte” na warunkach brazylijskich, czyli skanibalizowane. Else Ribeiro Pires Vieira, podsumowując radykalne założenia de Andradego, zauważa, że w manifeście pisarz bawi się słowem „Tupi”, które brzmi jak angielskie to be. „Tupi or not Tupi” (to be or not to be - „być albo nie być”) jest zatem skanibalizowanym cytatem z Szekspira:

1 Pierwszy polski przekład tego tekstu, autorstwa Darii Mikockiej, zamieszczamy na s. $37-45$ [przyp. red.]. 
Pochłonięcie Szekspira i odnowienie Hamletowskiego dylematu w Manifeście wskazuje na asymilacyjne perspektywy kanibalizmu zarówno jako postulatu, jak i praktyki: obcy wkład nie jest odrzucany, lecz absorbowany i przekształcany, dzięki czemu kanibalizm i zasada dialogiczna stają się sobie bliższe (Vieira 1999: 98).

Manifest de Andradego wywierał silny wpływ na brazylijski dyskurs krytyczny, a kilkadziesiąt lat później (od końca lat 60. XX wieku) także na teorię, a już zwłaszcza praktykę przekładu. Dwaj czołowi poeci i tłumacze, Haroldo i Augusto de Campos, podważyli binarny związek oryginału i przekładu. Używając metafory kanibalizmu, mówili o przekładzie jako wyjątkowym akcie kreacji. Literatura brazylijska jest „nie-źródłem”, a tłumacz ma prawo wchłaniać i przetwarzać każdy tak zwany oryginał. Jak twierdził Haroldo de Campos, jeśli przekład ma faktycznie być twórczy, musi się oderwać od związków łączących go ze źródłem, musi być (jak ujmuje to de Campos) „ojcobójczym odpominaniem”:

Każda przeszłość, która jest dla nas „innym”, zasługuje na swoją negację. Można powiedzieć, że zasługuje na to, by ją zjeść, wchłonąć. Należy pamiętać o tym doprecyzowaniu i wyjaśnieniu: kanibal był polemistą (od greckiego słowa polemos, które oznacza zmaganie lub walkę), ale był też ,,antologistą" - pożerał tylko tych przeciwników, których uważał za silnych, by odebrać im szpik i mięso, by wzmocnić się i odnowić własną, naturalną energię (de Campos 1963, cytowany w: Bassnett, Trivedi 1999: 103).

Pojęcie przekładu jako kanibalizmu upowszechniło się bardzo szybko, ponieważ zawiera w sobie szczególną strategię postkolonialną, dzięki której można wyjaśnić długo uznawaną za epistemologiczny pat implicytną władzę (europejskiego) oryginału nad przekładem. Prace braci de Campos zainspirowały całe pokolenie pisarzy i tłumaczy, nie tylko w ich własnym kraju i w Ameryce Łacińskiej, ale na całym świecie. Edwin Gentzler twierdzi, że metafora kanibalizmu stała się najważniejszym sposobem wyrażania niezależnej tożsamości, niezależności, która ,stwarza nowe uwarunkowania kulturowe, dające możliwość przemyślenia własnej przeszłości” (Gentzler 2008: 107).

Zwrot kulturowy w przekładoznawstwie poszerzył terytorium badań nad przekładem, odchodząc od wąskiego ujęcia lingwistycznego ku perspektywie społeczno-kulturowej. Badania nad historią przekładu ujawniają sposoby manipulowania tekstami przez tłumaczy w interesie kultury docelowej, zwłaszcza gdy mowa o przekładach z języków pozaeuropejskich na języki europejskie, 
a także wskazują na braki czy luki w narodowej historiografii literackiej, które można wyjaśnić tylko jeśli rozpozna się znaczenie przekładów w określonym czasie. Zwrot kulturowy odegrał istotną rolę w procesie wprowadzania kwestii ideologicznych do dyskursu o przekładzie i wyznaczył moment jednoznacznego zerwania z wcześniejszymi metodami opisu przekładu, skupionymi na zdekontekstualizowanych koncepcjach wierności i dokładności.

Nie należy jednak zakładać, że kierunek, w którym rozwinęło się przekładoznawstwo na Zachodzie, jest powszechnie przyjmowany. Współcześnie tacy chińscy przekładoznawcy jak Ning Wang, Martha Cheung i Nam Fung Chang (by wymienić tylko troje z nich), próbują stworzyć chiński dyskurs przekładoznawczy, który byłby odmienny od teorii zachodniej i od modeli postkolonialnych. Przypadek Chin jest interesujący, jako że w państwie tym istnieje długa tradycja teorii przekładu, ale także dlatego, że w latach 90. $\mathrm{XX}$ wieku, gdy Chiny zaczęły się otwierać na świat, nastąpił tam prawdziwy rozkwit działalności thumaczeniowej. Xie Ming w eseju Transvaluing the Global: Translation, Modernity and Hegemonic Discourse następująco podsumowuje chińskie dylematy:

We współczesnych Chinach globalizacja oznaczała głównie ciągły ruch przyciągania i tarcia. (...) Współczesne Chiny są zmuszone do globalizowania się pod dyktando Zachodu, mimo iż nigdy nie zrzekły się własnych tradycyjnych pretensji do chińskiej uniwersalnej kultury (i chińskiego imperium) (Xie 2008: 17).

Chińskie przekładoznawstwo zmaga się zatem z własnymi tradycjami wobec napływu zachodniej myśli przekładowej, zwłaszcza zaś wobec zwrotu kulturowego, zadając ważkie pytania o przydatność zachodnich modeli i zachodniego postkolonialnego dyskursu przekładoznawczego. Przekład jest dla współczesnych chińskich uczonych ważnym zagadnieniem: zmiany w chińskiej polityce doprowadziły do znacznego zapotrzebowania na tłumaczy, dlatego istotne stało się ich kształcenie, jak rówież dobre zrozumienie tego, co tak naprawdę dzieje się w thumaczeniu.

Podczas gdy Chiny zmierzają w kierunku większej świadomości językowej, wydarzenia z 11 września 2001 roku ujawniły niedostatek wykształconych tłumaczy z języków Bliskiego Wschodu w Stanach Zjednoczonych i odkryły drugą twarz niepodważalnej globalnej hegemonii języka angielskiego. Wobec dramatycznego obnażenia monolingwizmu Stanów Zjednoczonych, Emily Apter podjęła sformułowaną przez Mary Louise Pratt koncepcję „strefy kontaktu” - przestrzeni spotkania między narodami, strefy, w której dochodzi do transformacji dyskursywnych, gdy dane grupy ludzi próbują 
się zaprezentować innym ludziom. Strefa kontaktu może być miejscem, w którym dochodzi do przemocy, zaburzeń, opresji lub oporu, ale wciąż jest to przestrzeń teorii, w której można badać różnice kulturowe. Apter twierdzi, że próbowała sobie wyobrazić topografię intelektualną, która nie należy do pojedynczego narodu, ale jest „strefą krytycznego zaangażowania, łączącą „l” i „n” z transLacji i transNacji (Apter 2006: 5).

Apter definiuje przekład jako jednocześnie akt miłości i akt zakłócenia, wskazując, że przekład każe jednostkom opuścić strefę bezpieczeństwa przestrzeni narodowej i zmusza je do zmierzenia się z Innością. Doświadczenie nauki języków obcych to wyzwanie dla naszych oczekiwań, a rozpoznanie nieprzetłumaczalności zmusza do zmierzenia się z pytaniem o granice jednego określonego języka. Jak twierdzi Apter, przekład jest zatem ,istotnym medium przekształcania podmiotu i zmiany politycznej" (Apter 2006: 6). Przekład ma wymiar zarówno jednostkowy, jak i polityczny.

Apter chce odzyskać pojęcie przekładu jako podstawowego wymiaru współczesnej komunikacji oraz sedno definiowanej przez nią nowej komparatystyki literackiej. Zdaniem badaczki, przekład jako metafora i praktyka przekładowa nie są sobie przeciwne. Docenia ona zasadność zarówno badań przekładoznawczych, jak i myśl teoretyków reinterpretujących Waltera Benjamina w świetle teorii postkolonialnych, od Derridy po Gayatri Chakravorty Spivak. W jej opinii, przekład staje się podstawowym środkiem wyrazu dla współczesnego oglądu, który stara się uwzględniać rozmaite formy komunikacji.

Podobne górnolotne tezy o znaczeniu przekładu można znaleźć w książce innej komparatystki, Belli Brodzki, Can These Bones Live? Translation, Survival and Cultural Memory. Brodzki uważa, że przekłady nie tworzą odrębnej sfery produkcji literackiej - przekłady są przepisaniami (re-writings) i jak każde przepisanie, tak i one korzystają z odczytań i powtórnych odczytań. Przekłady są zatem tekstami, które odzwierciedlają zmieniające się uwarunkowania i konteksty społeczno-polityczne, w jakich powstają. Brodzki twierdzi, że tłumaczenie nie jest jedynie technicznym procesem przekładania tekstu zapisanego w jednym języku na inny język - jest też zjawiskiem tworzącym podwaliny ,wszystkich transakcji kulturowych, od najczystszych po najciemniejsze" (Brodzki 2007: 2) i zasługuje na taką uwagę, jaką w analizach kulturowych cieszą się rozważania nad gender.

Tak jak niemożliwe stało się badanie zagadnień takich jak na przykład kwestia autorstwa, sprawczości, podmiotowości, performatywności, wielokulturowości, 
postkolonializmu, transnarodowości, pisarstwa diasporycznego i literatury cyfrowej bez uwzględnienia gender jako kategorii analitycznej, tak niemożliwe powinno być pominięcie integralnej roli tłumaczenia w każdej dziedzinie dyskursu (Brodzki 2007: 2).

Brodzki i Apter to dwie kluczowe postaci przenoszące komparatystykę literacką w nową erę. Krytyka starych modeli komparatystyki literackiej, książka Death of a Discipline Gayatri Spivak, pojawiła się w roku 2003, a autorka nawoływała do zaprzestania konfrontacji między komparatystyką a studiami kulturowymi/etnicznymi, kładąc nacisk na centralne miejsce przekładu oraz ruch ku nowej perspektywie planetarnej. Odpowiedzią na to nawoływanie w XXI wieku jest gwałtowny rozwój literatury światowej jako dziedziny badawczej. Spivak mówi o problematycznym statusie narodu w tradycyjnej komparatystyce literackiej, jak również o marginalizacji tłumaczeń, i twierdzi, że nadszedł już czas, by ruszyć dalej.

Książka Madsa Rosendahla Thomsena Mapping World Literature. International Canonization and Transnational Literatures (2008) opisuje parametry tej dziedziny i wyjaśnia jej związek z komparatystyką i z postkolonializmem, przywołując prace takich badaczy, jak Pascale Casanova, David Damrosch i Franco Moretti. Thomsen wchodząc na ten trudny teren sugeruje, że postkolonializm „nie przyniósł zbyt przekonujących koncepcji i metod opisu literatur tradycyjnych centrów, dawnych kolonizatorów" (Thomsen 2008: 25). Powielając tezy Spivak, Thomsen twierdzi, że wskazany błąd doprowadził do ,,irracjonalnego podziału” na przedmiot badań komparatystyki i studiów postkolonialnych. Uznając, że przekładoznawstwo jest mocniej związane na tym etapie rozwoju z komparatystyką literacką, możemy dostrzec, że ten irracjonalny podział stanowi kolejną odsłonę konfliktu między przekładem jako praktyką i przekładem jako konceptualizacją filozoficzną, któremu przeciwstawia się Harish Trivedi. I rzeczywiście, jeśli teoretycy postkolonializmu ignorują przekładoznawstwo, to przekładoznawstwo ogólnie jest dużo bliższe metodologiom starej komparatystyki literackiej. Badanie thumaczeń literackich w obrębie modelu literatury światowej niweluje te konflikty, pozwala bowiem spojrzeć na nie pod kątem globalnych przepływów, a tłumaczenie jest w samym sercu tego rodzaju ruchów.

Doris Bachmann-Medick dowodzi, że w humanistyce w ogóle doszło do „zwrotu przekładowego”. Horyzont poznawczy przekładu poszerza się i różnicuje, dlatego też przekład jest 
analitycznym pojęciem teorii społecznej, teorii działania, teorii kultury, mikrosocjologii, badań nad migracjami, historii, teorii interkulturowości i tak dalej, które nie funkcjonuje wyłącznie na poziomie metaforycznym, ale jest ujmowane na podstawie procesów empirycznych (Bachmann-Medick 2009: 4).

Zwrot przekładowy nakłada się na poszukiwania nowej perspektywy planetarnej, wizji literatury światowej, która nie jest skupiona wokół modeli europejskich, rewizji roli tłumaczenia jako czynnika umożliwiającego powstanie strefy kontaktu. Być może najważniejsze jest to, że ów zwrot stanowi dowód na przyznawanie przekładowi większego znaczenia we wszystkich transakcjach kulturowych, zarówno metaforycznych, jak i dosłownych, i (miejmy nadzieję) przyczyni się do zniesienia sztucznych podziałów między różnymi dziedzinami badań.

\section{Przełożył Jakub Czernik}

\section{Bibliografia}

Alvarez R., Carmen-Africa V. (red.). 1996. Translation, Power, Subversion, Clevedon: Multilingual Matters, s. 79-88.

Apter E. 2006. The Translation Zone. A New Comparative Literature, Princeton: Princeton University Press.

Asad T. 1986. The Concept of Cultural Translation in British Social Anthropology, w:

J. Clifford, G. Marcus (red.), Writing Culture, Berkeley: University of California Press, s. 140-164.

Bachmann-Medick D. 2009. Introduction: The Translational Turn, „Translation Studies” 2(1), s. 2-16.

Bassnett S. 2002. Translation Studies, 3 wyd., London: Routledge.

Bassnett S., Lefevere A. (red.). [1990] 1995. Translation, History and Culture, London: Cassell.

Bassnett S., Lefevere A. 1998. Constructing Cultures, Clevedon: Multilingual Matters. Bassnett S., Trivedi H. (red.). 1999. Postcolonial Translation. Theory and Practice, London: Routledge.

Benjamin W. 2011. Zadanie tlumacza, przeł. A. Lipszyc, „Literatura na Świecie” 5-6, s. $27-41$.

Bhabha H. 2010. Miejsca kultury, przeł. T. Dobrogoszcz, Kraków: Wydawnictwo Uniwersytetu Jagiellońskiego.

Brodzki B. 2007. Can These Bones Live? Translation, Survival and Cultural Memory, Stanford: Stanford University Press. 
Bukowski P., Heydel M. (red.). 2009. Współczesne teorie przekładu. Antologia, Kraków: Wydawnictwo Znak.

Carbonell O. 1996. The Exotic Space of Cultural Translation, w: Alvarez R., Carmen-Africa

V. (red.), Translation, Power, Subversion, Clevedon: Multilingual Matters, s. 79-88.

Cheyfitz E. 1991. The Poetics of Imperialism. Translation and Colonization from „, The

Tempest” to „Tarzan”, New York-Oxford: Oxford University Press.

Dingwaney A., Meier C. (red.). 1995. Between Languages and Cultures. Translation and

Cross-Cultural Texts, Pittsburgh-London: University of Pittsburgh Press.

Even-Zohar I. 2009. Miejsce literatury ttumaczonej $w$ polisystemie literackim, przeł.

M. Heydel, w: P. Bukowski, M. Heydel (red.), Współczesne teorie przekładu. Antologia, Kraków: Wydawnictwo Znak, s. 197-203.

Fenton S., Moon P. 2002. The Translation of the Treaty of Waitangi: A Case of Disempowerment, w: M. Tymoczko, E. Gentzler (red.), Translation and Power, Amherst: University of Massachussetts Press, s. 25-44.

Gentzler E. 2008. Translation and Identity in the Americas, London: Routledge.

Hofmeyr I. 2004. The Portable Bunyan. A Transnational History of ,, The Pilgrim's Progress", Princeton: Princeton University Press.

Holmes J. 2000. The Name and Nature of Translation Studies, w: L. Venuti (red.), The Translation Studies Reader, London: Routledge, s. 172-185.

Lefevere A. 1992. Translation, Rewriting and the Manipulation of Literary Fame, London: Routledge.

Niranjana T. 1992. Siting Translation. History, Post-structuralism, and the Colonial Context, Berkeley: University of California Press.

Rainer S., Biguenet J. (red.). 1992. Theories of Translation. An Anthology of Essays from Dryden to Derrida, Chicago-London: University of Chicago Press.

Rushdie S. 2013. Ojczyzny wyobrażone. Eseje i teksty krytyczne 1981-1991, przeł.

E. i T. Hornowscy, Poznań: Dom Wydawniczy Rebis.

Sapir E. 1978. Kultura, język, osobowość. Wybrane eseje, przeł. B. Stanosz, R. Zimand, Warszawa: Państwowy Instytut Wydawniczy (esej: Status lingwistyki jako nauki, pierwodruk: 1927. The Status of Linguistics as a Science, „Language” V, s. 207-214). Sengupta M. 1995. Translation as Manipulation: The Power of Images and Images of Power, w: A. Dingwaney, C. Meier (red.), Between Languages and Cultures. Translation and Cross-Cultural Texts, Pittsburgh i London: University of Pittsburgh Press, s. $159-180$.

Soyinka W. 1976. Myth, Literature and the African World, Cambridge: Cambridge University Press.

Spivak G.Ch. 2003. Death of a Discipline, New York: Colombia University Press.

Thomsen M.R. 2008. Mapping World Literature. International Canonization and Transnational Literatures, London: Continuum.

Trivedi H. 2007. Translating Culture vs. Cultural Translation, w: P. St-Pierre, P.C. Kar (red.), In Translation - Reflections, Refractions, Transformations, Amsterdam: John Benjamins Publishing Company, s. 277-287.

Tymoczko M., Gentzler E. (red.). 2002. Translation and Power, Amherst: University of Massachussetts Press. 
Venuti L. 1995. The Translator's Invisibility. A History of Translation, London: Routledge.

Venuti L. (red.). 2000. The Translation Studies Reader, London: Routledge.

Vieira E.R.P. 1999. Liberating Calibans: Readings of „Antropofagia” and Haroldo de Campos' Poetics of Liberation, w: S. Bassnett, H. Trivedi (red.), Postcolonial Translation: Theory and Practice, London: Routledge, s. 95-113.

Wang N., Yifeng S. (red.). 2008. Translation, Globalisation and Localisation. A Chinese Perspective, Clevedon: Multilingual Matters.

Xie M. 2008. Transvaluing the Global: Translation, Modernity and Hegemonic Discourse, w: N. Wang, S. Yifeng (red.), Translation, Globalisation and Localisation. A Chinese Perspective, Clevedon: Multilingual Matters, s. 15-30. 